\title{
The Impact of Corporate Characteristics on Social and Environmental Disclosure (CSED): The Case of Jordan
}

\author{
Tareq Bani-Khalid ${ }^{1}$, Reza Kouhy ${ }^{2}$ and Aminu Hassan ${ }^{3}$ \\ ${ }^{1}$ Faculty of Finance \& Business Administration, Al al-Bayt University, Mafraq, Jordan \\ 2,3 Dundee Business School, University of Abertay Dundee, Scotland, UK \\ Correspondence should be addressed to: tareq alkhaldi; tareq_alkhaldi@yahoo.com
}

Received date: 27 September 2016; Accepted date:19 December 2016;

Published date: 16 February 2017

Academic Editor: Mahmoud Al-Sayed

Copyright (C) 2017. Tareq Bani-Khalid, Reza Kouhy and Aminu Hassan . Distributed under Creative Commons CC-BY 4.0

\begin{abstract}
The corporate business environment is surrounded by strong public scrutiny from diverse stakeholder groups that are calling on businesses to accept accountability for not only their financial actions, but also the non-financial implications of their activities. Many corporate businesses are today paying attention to the needs of their stakeholders of social and environmental information. As such, in this study we examined how corporate characteristics could influence the amount of Corporate Social and Environmental Disclosure (CSED) in the manufacturing sector in Jordan. Firm size, profitability, audit firm, ownership, type of industry and financial market level are the main factors examined in this study. Drawing from Ernst and Ernst methodology, the study developed a disclosure index to measure the amount of CSED for three years (2010, 2011 and 2012). Using panel data regression, we model the relationship between disclosure amount and the key drivers of CSED via random effect estimation. The results of our model indicated that the firm size, type of audit firm and financial performance in Amman Stock Exchange (ASE) are significantly associated with the amount of CSED. On the other hand, we also find that firm profitability, age, type of industry and ownership are not related to the practices of CSED.
\end{abstract}

Keywords: Disclosure, CSED, Stakeholder Theory, Disclosure index, Jordan

\section{Introduction}

In the past, responsibility of organizations was an economic performance in the first place, as the continuation of the organizations requires a commitment to maximize profits for shareholder groups (Balabanis et.al, 1998). However, focusing only on financial performance without any considerations to social and environmental impacts becomes a source of global concern to many stakeholder groups especially with

Cite this Article as: Tareq Bani-Khalid, Reza Kouhy and Aminu Hassan (2017), " The Impact of Corporate Characteristics on Social and Environmental Disclosure (CSED): The Case of Jordan ", Journal of

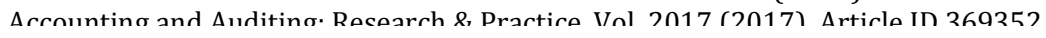


the increasing cases of corporate collapse over non-financial issues during the last decades (Ql-Oquili \& Kouhy, 2006). Corporate response to these global concerns led to the emergence of the concept of Corporate Social and Environmental Responsibility (CSER) as a western phenomenon in the business literature (Macarulla \& Talalweh, 2012; Bewley et al., 2000; Patten, 1992; Ullmann, 1985).

Corporate responsibility for not only their financial actions, but also the non-financial implications of their activities has become a challenge for many countries, especially in the developed world (Macarulla \& Talalweh, 2012). Particularly, Corporate Social Environmental Responsibility (CSER) practices in these countries such as Europe, USA and Canada gained increasing importance in the literature of accounting, as numerous western studies confirmed that the profit standard is no longer the only approach used to evaluate corporate performance (Bhattacharyya 2015, Adams \& Kuasirikun, 2004).

Meanwhile, the non-financial activities are considered as important as financial activities (D'Amato et al 2009). In essence, the two are considered positively related as Thomas and Hunger (2008) specifically argue that corporate business activities should be run in a socially acceptable way if they desire to improve their image, and establish credibility for their actions with their various stakeholders. Because building a good relationship with the stakeholders in the long run can ensure sustainability of a business (Uddin et al 2008), thus, business sustainability would be helpful to create value for all stakeholders (Woodward et al., 1996).

Similarly, it is documented by several western studies including for example those conducted by Griffin and Mahon (1997), Roman et al (1999), and Rowley and Berman (2000) that, CSER strategy is an important means to contributing to global sustainability. And this is the reason why CSER initiatives currently have gained so much importance in those countries (Uddin et al 2008).
Contrary to developed countries, corporate social and environmental responsibility (CSER) is reported as being at infancy stage in the Jordanian business environment (Ismail \& Ibrahim, 2008). As many developing countries, many Jordanian stakeholders continue to suffer from a lack of public awareness with regard to the importance of CSER practices. This low level of awareness has led to many violations of local community rights and the surrounding environment, despite the fact that Jordan has recently issued a new set of regulations to govern business processes (Ismail \& Ibrahim, 2009).

Before 2000, it is argued that the government regulations related to corporate non-financial issues were not eligible to enforce CSER initiatives in Jordan, or at least encourage companies to adopt better CSER practices as they are still limited to specific financial requirements (AlBitar, 2012). Indeed, social and environmental practices of companies operating in Jordan were considered to be a part of their philanthropy framework rather than taking it as a main approach for their sustainable development (AlBitar, 2012). In other words, a large number of companies whether in Jordan or any developing country are more concerned about how much profits are generated and how much dividends are paid, paying no attention to social and environmental issues (Sani, 2015). The periods of 1990 s are regarded as an incubation stage of CSER by corporate bodies. That is largely because most Jordanian companies have not been able to fully grasp CSER and sustainability practice.

However, the year 2000 to present are considered as periods in which corporate organisations realise the importance of establishing standards that shall help them be seen as behaving responsibly either as other stakeholders. Furthermore, in 2000's, the Jordanian government made some effort to raise the level of the social and environmental responsibility of business. Indeed, Jordan has recently witnessed a true movement in the company's initiatives of social and environmental activities by enacting a new set of social and environmental legislations and sustainability forums across the country 
(Al-Zu'bi, 2011). For example, (i) in 2003 the Ministry of the Environment (MoE) was established with the aim of improving and maintaining the quality of the Jordanian environment, conserving natural resources and contributing to the sustainable development of the country, and (ii) the Environment Protection Law No. 52 of 2006 was passed, which is considered the main legal framework for protection and management of social and environmental life and to provide legal protection for citizens and workers and the local community.

Nowadays, especially with the increasing strategic decisions by companies that involve potential social and economic consequences (Jones et al 2007), many businesses in Jordan realize the importance of being officially responsible to their stakeholders, by the reporting of their CSER activities. As such, CSED is said to be a way for providing such CSER information that may satisfy accountability relationships with stakeholders (Gray, 2000). Through this accountability, it helps in creating a just society among business corporations (Deegan \& Gordon, 1996). It is also documented as a strategy to legitimize corporate existence (O'Donovan, 2002; Brown \& Deegan, 1998). CSED is also an indication of corporate moral consciousness on social and environmental issues (Shearer, 2002). Social and environmental disclosures are found significantly useful in enhancing corporate financial performance (Waddock \& Graves, 1997; Blacconiere, 1994). In the overall, it can be argued that CSED is a successful strategy to make a corporation more acceptable in society's eyes.

CSED, in its broadest sense, is defined as supplementary disclosure of information in the corporate reporting, aiming to inform society about their social and environmental rights (Hassan, 2010). From this perspective, this type of disclosure gives the corporate reporting a great reliability that would enhance the confidence of stakeholders to make more informed investment decisions. Hence, this paper sets out to examine the extent and the potential determinants of CSED practices in Jordan for a sample of manufacturing listed companies for the period of 2010-2012. We examine the degree to which firm characteristics (i.e., company size, age, profitability, industry type, ownership type and audit type) affect CSED practices. It also concentrates on how to understand and explain organisational behaviours that recognise other claimants' rights in their environments according to stakeholder theory.

Hence, the focus of this study shall be on all non-financial disclosures by the Jordanian manufacturing companies, in terms of patterns and amount of CSED information that was reported in the annual reports during 2010.2011 and 2012.

\section{Stakeholder Theory and CSER Disclosure}

According to Langtry (1994), stakeholders in accounting literature refers to individuals or groups who have a stake in or a legitimate claim on the firm. Furthermore, It has been stated by Freeman (1984) that any group or individual that can affect or is affected by the achievement of an organisation's objectives can be called a stakeholder. The Stanford Research Institute (SRI, 1963) defines the term stakeholders as "those groups without whose support the organisation could cease to exist" (Freeman et al., 1983, p. 89).

From the definitions above, it can be understood that the philosophical framework of the stakeholder theory is based on trying to pay attention to all parties that are associated with companies, either through a direct or an indirect relationship. Differences in the level of this relationship, balancing of economic and social interests and equal treatment among all stakeholders, are the key ideas that underlie this theory (Harrison \& Freeman, 1999).

Stakeholder theory is one of the most prominent strategic issues for companies relating to how to manage their relationship with stakeholders. This theory seeks to interpret the complex relationships and regulatory interactions, which intertwined between the external and internal environment for companies. Therefore, the basic argument for the stakeholder theory is an attempt to expand the concept of 
individuals who have a legitimate claim on the firm from shareholder into stakeholder (Marcoux 2003; Solomon \& Linda 2002 and Gray et al, 1996). In the same vein, Gray et al (1996) argue that, stakeholder theory is focused on identifying the responsibility and accountability between a firm and its stakeholders, which seeks to encourage corporate bodies to align corporate needs with its environment (Aribi, 2009).

According to this perspective, it could be argued that the stakeholder groups have the capacity to manipulate/control how companies perform their duties (Wilson, 1997). In this regard, Gray et al., (1995: p53) argue that: the corporation's continued existence requires the support of the stakeholders and their approval must be sought and the activities of the corporation adjusted to gain that approval. The more powerful the stakeholders, the more the company must adapt; social disclosure is thus seen as part of the dialogue between the company and its stakeholders.

In line with the stakeholder theory, CSED is considered as an effective mechanism to be used by organisations for managing and developing relationships with its stakeholders, in order to gain their support and approval, or to distract their opposition (Gray et al, 1996, p.46). Similarly, Roberts, (1992) asserts that the CSED is one of the most successful means in the interpretation and negotiation of the relationships between the internal and external parties. Moreover, Guthrie and Parker (1990; p. 171) argue that the CSED is an important way "to reflect public social priorities, respond to government pressure, accommodate environmental pressures and sectional interests and protect corporate prerogatives".

Thus, from the above, stakeholder theory is considered as the theoretical perspective for the purpose of explaining variations in CSED practices and its determinants. However, literatures have reported various factors that determine the extent of corporate social and environmental disclosures which were broadly classified into two categories (Adams, 2002). These are:
1) Corporate characteristics as internal factors influencing the corporate nonfinancial disclosure, such as size, profitability, age, type of industry the company belongs to etc.

2) General contextual factors as external factors influencing the practices of CSED, such as country of origin, economic development, political context, culture, media pressure, power of stakeholders etc.

Based on the above classification, this study specifically examines the degree to which firm characteristics affect CSED practices. As such, some aspects of each of the above broadly classified internal factors are presented below, which can be developed as explanatory variables within the next subsection of this paper.

\section{Determinants of Corporate Social and Environmental Disclosure}

A number of empirical studies like Hanafi (2006), Ahmad, (2004), Haniffa \& Cooke (2002) and Adams and Kuasirikun (2000) indicated that the analysis of the factors that influence the level of CSED is one of the major considerations to find out stakeholder needs of social and environmental information, and to avert conflict in the legitimacy relationship between stakeholders and companies. Based on the studies above, this paper will deal with the major corporate characteristics that affect the level of CSED as determinant factors.

According to Gray et al. (2001; p.238), there has been an increase of CSED studies "...in both size and complexity over the last two decades....unsurprising". But, what is surprising is that there is "increasing attention from stakeholders and its regulators", to explain and understand an area of corporate characteristics and impact on the level of CSED, for example: Holder Webb et al, 2009; Belal \& Owen, 2007; Hanafi 2006; Cormier \& Magnan, 2003; Gray et al. 2001; Adams et al., 1998; Hackston \& Milne, 1996; Gray et al., 1995; Patten, 1992; Zeghal \& Ahmed, 1990; Cowen et al., 1987.

Previous studies have focused on examining the statistical relationship between the level of CSED of the firm and their characteristics, 
through a set of CSED determinants. In general, the above studies revealed that company size, age, type of industry, profitability, financial performance, ownership structure and audit firm are the most frequently identified factors. Therefore, this paper will address the most important factors that have already been used in most studies from a statistical perspective for the following reasons:

- The majority of CSED studies have used the above previous determinants based on the different theories. This provides the possibility of comparison between the results of the previous literature with the results of this paper, especially as it relies on stakeholder theory to justify CSED practices

- Previous CSED studies have used the statistical tests to interpret the relationship between firms' determinants and level of CSED; therefore, this paper also will rely on statistical analysis to find out the impact of previous determinants on the level of CSED, given that this technique provides the possibility of obtaining more accurate data, thus, the ability to be measured easily

- There are very limited studies - to the best of the researcher's knowledge - that have attempted to explain the impact of corporate characteristics on the level of CSED in the Jordanian context; thus giving this study a motivation to examine and explain the impact of these factors on CSED practices, in order to find out the level of these non-financial practices in this developing country

Below is a summary of each of the relevant characteristics. Therefore, based on the above points, the key questions that could be raised here are:

Q1: What is the level of CSED practices in the annual reports of Jordanian industrial corporations?

Q2: Do the characteristics of firms determine the level of CSED in the Jordanian annual reports?

\section{Company Size}

Corporate size is one of the factors potentially associated with the level of social and environmental information. Also it has a direct impact on the level of CSED in terms of the quality and amounts. In this regard, it cannot be excluded when measuring the level of CSED practices (Gray et al., 1995a, 2001). Ince (1998) has criticized the study of Ness and Mirza (1991) which did not take into account the size effect on the level of CED, when he mentioned that "One needs to be careful in evaluating the conclusions drawn from Ness and Mirza's (1991) work. The reason for this is that, first of all, size effect was not taken into account in their study" (p.55).

Company size has been viewed from different perspectives. For instance, Hanafi (2006); Naser et al., (2006) and Williams (1999) used firm's market capitalization to measure the impact of firm's size on the level of CSED. Yao et al (2011), Cormier et al. (2010) and Trotman and Bradley (1981) used total assets as company size. Whilst Belkaoui and Karpik (1989); Hossan, (2010) and Freedman and Jaggi (1988) used return on assets to measure the level of CSED. But, Hackston and Milne (1996) used all of the above measures in their study.

Despite the differences in the approach of company size, results from the previous studies indicated that the size of the firm is an important determinant of CSED as larger firms make better disclosures. Patten (2002) argues that larger firms -often- are a more detailed disclosure than small-sized companies with regard to CSR information. In this regard, Hanafi (2006: p.229) adds that the reason behind that "super-large companies are significantly more likely to disclose more of all types of corporate social and environmental information. These companies are subject to more public scrutiny by virtue of their size; they receive more attention, and are under greater potential pressure".

Many studies that found positive relationship between firm's size and disclosures include (e.g. Wang et al 2013; Uyar et al 2013; Yao et al, 2011; Parsa \& Kouhy, 2008; Ghazali, 2007; Hanafi 2006; Gray et al., 2001; Hackson \& Milne, 1996; Cowen et al., 1987, and Trotman and Bradley, 1981). In contrast, other studies 
(e.g. Bayoud \& Kavanagh, 2012; Hussainey et al, 2011; Roberts, 1992; Ng, 1985 and Singh \& Ahuja 1983) found that the firm's size is not significantly associated with the level of CSED.

From the aforementioned, it could be argued that there is a relationship between the size of the company, the level of CSED and pressures of stakeholder groups. Thence, according to the view of Ince (1998), larger firms are subject to stronger pressure from stakeholder groups than the firms that have a few stakeholders. Consequently previous results support the perception of stakeholder theory, which argues that firms are seeking to maintain good relations with stakeholders and avoid their pressures, through meeting their needs of social and environmental information (Kakabadse et al., 2005; McWilliams and Siegel, 2001). Therefore, the discussion above leads to the sub first key hypothesis that could be raised here which is: There is no relationship between corporate size and level of CSED practices in the Jordanian annual reports.

\section{Type of Industry}

Several empirical CSR studies indicated that there is a significant evolution in the level and patterns of CSR disclosure, largely associated with the type of corporate industry (Waddock \& Graves, 1997, Hackston \& Milne, 1996).

Despite the evolution of the CSED level that was mentioned by Waddock and Graves, (1997) and Hackston and Milne, (1996), there are still variations in the items of CSED across different types of industry sector (Bayoud \& Kavanagh, 2012; McGuire et al., 2003; Gray et al., 2001; Hackston \& Milne, 1996; and Gray et al., 1995). For example, Hackston and Milne (1996) assert that there was variation in the level of disclosure based on the type of industry, they argue that "such as extractive industries, are more likely to disclose information about their environmental impacts than are companies in other industries" (p.82).

Also, Bayoud and Kavanagh, (2012: p.13) added that "Companies in the oil sector are more focused on environmental issues, while companies in the food sector are involved more in community, health and food related CSR activities...., while the manufacturing sector is more disclosed about community, safety and health related to CSR categories".

From above, it could be argued that the nature of the company's activity has a significant role in determining the patterns of social and environmental information disclosure. In this context, many studies have indicated through their results the existence of a positive relationship between type of industry and level of CSED (e.g. Wang et al 2013; Bayoud \& Kavanagh, 2012; Parsa \& Kouhy, 2008; Rizk et al 2008; Ghazali, 2007; Hanafi 2006; Gray, 2001; Adams 1998; Gamble et al., 1995; Singh \& Ahuja 1983).

Previous studies found that the level of CSED was not on the same level of consistency, compared with the same factor (type of industry), as shown in the quotation above. For example Kelly (1981) found that there was some variance in the positive relationship with the CSD patterns among types of industry, as such: primary and secondary industry companies tended to disclose environmental and energyrelated information more than corporations engaged in service industry. Also, Ness and Mirza (1991) found that there was strong relationships between the oil industry and CSD patterns. On the other study, Gamble et al., (1995) found that there was a correlation between the quality and patterns of CSED and the nature of the company's activity, especially in the sector of hazardous waste management. In this regard, Patten, (1992) argues that the variations of CSED patterns are a result of the difference in firms' activities and stakeholders' needs as well.

On the other hand, certain studies (e.g. Hanafi, 2006; Newson \& Deegan, 2002; Choi, 1999; Hackston \& Milne, 1996; and Patten, 1992) have tried to determine the impact of the main activity for industry on the level of CSED, by classifying industries depending on the type of activities practiced by firms into two types; (i) high profit firms or those operating in highly environmentally sensitive industries, (ii) 
low profile firms that are operating in lower environmentally sensitive industries.

Based on the above category, the results of the previous studies indicated that the industries that are highly environmentally sensitive, have a lot of social and environmental disclosures, compared with industries that have lower levels of sensitivity towards the environment. In contrast, other studies in the same area, found that there was no impact for the type of industry on the level of CSED, for example; Cowen et al. (1987) and Sahay, (2004).

In this regard, this paper will examine the level of CSED by the Jordanian industrial sector, accordance to ASE classification in 10 sub-sectors. Thus, a broad research hypothesis could be raised here which is: There is no relationship between type of Industry and level of CSED practices in the Jordanian annual reports.

\section{Profitability of Firms}

In respect of corporate profitability effects on CSED level, there is an obvious variation in the results of studies that have addressed the impact of firms' characteristics on the level of CSED. For example, Murray et al., (2006) examined the relationship between profitability and level and patterns of CSD related to environmental, community, employee and customer issues. The sample of this study included the top 100 companies in the UK sectors during 10 years (Chemicals, Oil and Gas; Pharmaceuticals; General Manufacture; and Extractive). The results show that there was a variation in the associations between profitability and level of CSD, as such (the correlations between profitability and the level and nature of CSD practices from 1989-1992 were low but positive. Between 1993-1996, it was very close to zero and a negative relationship was observed during 1996- 1997).Thus, Murray et al., (2006) suggest "an inverse relationship exists between share returns and these variables but none of the negative values are statistically significant"(p. 240).

It seems that the result of Murray et al., (2006) about the relationship between profitability and patterns of CSD, was consistent with the results of (Uyar et al 2013; Bayoud \& Kavanagh, 2012; Ghazali, 2007; Naser et al. 2006; Hackston \& Maline, 1996; Belkaoui \& Karpik, 1989 and Cowen et al. 1987). In contrast, there are also many studies that disagreed with the results of Murray et al., (2006) such as (Hussainey et al, 2011; Samaha \& Dahawy 2011; Hanafi, 2006; Haniffa \& Cooke, 2005; Gray et al. 2001; Singh \& Ahuja, 1983) who have found a significant relationship for this variable.

Generally, profitability is considered as one of the determinants that cannot be ignored because of its impact on the level of CSED. Therefore, based on the above negative results, Ullman (1985) argues that the reason for these contradicting results can be caused by weakness in the methodology of these studies, which did not have a relationship between CSRD and profitability. Hence, the firms that have a strong economic edge (based on high profits) automatically have a lot of CSED, and maybe considered by stakeholders as socially responsible (Cormier et al., 2005). This also raises stakeholder confidence regarding those firms' profitability. Ullman (1985) argues that Economic performance determines the relative weight of a social demand and the attention it receives from top decision makers. In periods of low profitability and in situations of high debt, economic demands will have priority over social demands (p.553).

Based on the above findings, there is a hypothesis that dominates the above debate: There is no relationship between corporate profitability and level of CSED practices in the Jordanian annual reports.

\section{Corporate Ownership}

According to Jensen and Meckling (1976), the agency theory assumes a separation between ownership of firms and control of a firm, to attempt to reduce agency costs in addition to the reduction in the conflict of interest between stakeholders groups. So that, each party of stakeholders has the ability to choose its actions optimally in its self-determined goals (Ince, 1998). Further, Smith, et al, (2005. p.131) believe that "ownership structure may influence the relationship between companies and 
stakeholders, and influence the level of quantity and quality of CSD"

Moreover, Haniffa and Cooke (2005), underscore diversity of ownership structure as a key contributing factor to the reduction of the legitimacy gaps between firms and stakeholders. According to Freeman (1984), stakeholder theory is a model to management of conflicts and achieving a balance among groups that have, or claim, ownership, rights, or interests in a corporation and its activities. In this context, it is important to examine the impact of ownership structure on the level of CSED, which has been highlighted in the above theoretical review.

Based on the above discussion that examines the relationship between corporate ownership structure and the patterns of CSED, it is considered as one of the common features to the many CSR studies that have been conducted during the last 20 years, for example (Cormier et al. 2011; Rizk et al. 2008; Ghazali, 2007; Naser et al. 2006; Haniffa \& Cooke, 2005; Adams, 2002; Gray et al.1995; Patten,1992; Guthrie \& Parker, 1990; Andrew et al. 1989; and Teoh \& Thong 1984).

According to Gao et al (2005) and Gray et al. (1995) reviews, the affiliation to the firm's ownership is an important determinant of CSED level. The majority of previous studies indicated in their findings the existence of a significant effect of the corporate ownership on the level of CSED.

However, the same studies indicated that there were differences in the level of CSR disclosure based on the diversity of the internal structure of corporate ownership. For example; Ghazali, (2007) in examining different relationships in firm ownership and the influence of firm ownership (director ownership, government ownership and ownership concentration), established that director ownership and government ownership significantly influence CSED, while ownership concentration is not statistically significant in explaining the level of CSD.

Moreover, Naser, et al, (2006) examined the impact of governmental ownership, institutional ownership, and major shareholders on the level of CSED. The results pointed out that there is an impact of institutional ownership and governmental ownership on the level of CSED, whilst ownership of major shareholders does not have a relationship with the level of CSED.

On the other hand, Andrew et al. (1989) studied the impact of foreign ownership and local ownership on the level of CSED. They found that there is a positive relationship between ownership and the level of CSED. But, CSED is mostly associated with the larger and foreignowned companies. Conversely, Haniffa and Cooke, (2005) results confirmed a significant relationship between firm ownership (Malay directors, Malay shareholders and foreign shareholders) and the level of CSD in the annual reports of Malaysian companies.

With regard to private and public ownership, Ahmed (2004) found that the CSED in the corporate private ownership is more than the disclosures in corporate public ownership. On the same note, Rizk et al. (2008) found that these are significantly affected by the level of CSED by private companies more than the corporate government ownership. In this context, Rizk et al. (2008) argue that "Legitimacy theory gives us a probable explanation for this fact. It can be argued that increased environmental disclosure by private companies is a strategy employed by Egyptian organizations to ensure/maintain their organizational legitimacy" (p.321)

In this regard, Ghazali, (2007) argues that the diversity of firms' ownership reflects a variety of perceptions of stakeholders between supporters and opponents of CSED policy. For example, Roberts, (1992) and Ullman, (1985) argued that the level of firm ownership that is concentrated in the hands of a few persons might be of negative consequence effect on the firms' interests. Moreover, Yao et al., (2011) argue that the firms that have a more diversified ownership structure have a big "willingness to share their CSR information with the public" (p.25). The opinion of Yao et al., (2011) stems from the disclosures policy which takes into account the provision of 
CSED to stakeholders as a means to reduce conflicts among various stakeholders.

Based on the sample of this paper, Jordanian industrial sectors will be within the scope of this research to investigate corporate ownership through government and public ownership. Thus, a broad research hypothesis could be raised here: There is no relationship between ownership structure and level of CSED practices in the Jordanian annual reports.

\section{Type of Audit Firm}

The selection of the audit firm type as one of the important factors that affects the level of CSED practices is based on evidence in the literature of CSR (Hussainy et al. 2011). For example, Khasharmeh and Desoky (2013) argue that, "An auditing firm may have a significant role to play with respect to the amount of information disclosed by the company" (p.47). Moreover, Hail (2002) sees that the type of audit firm is an important factor in improving firms' reporting practices.

Although the type of auditor is an important factor to facilitate the disclosure of corporate information, Hussainy et al.(2011) argue that the previous literature has submitted mixed results regarding the impact of the type of auditor firm on the level of CSED practises. Several studies have indicated that the international audit firms such as big- 4 audit firms has a significant influence on the level of CSED in corporate reports than the local audit firms (e.g. Samaha \& Dahawy 2011; Hussainy et al. 2011; Barako et al 2006; Hossain et al. 2006; and Xiao et al., 2004). In contrast, other studies have indicated that there is no relationship between audit type and CSED practises in the annual reports (Khasharmeh \& Desoky, 2013; Huafang \& Jianguo, 2007; Chau \& Gray, 2010).

Based on the discussion above, this paper seeks to explore the impact of the audit firm type on the level of CSED in annual reports. Thus, Big 4 audit firms will be employed in this paper for two reasons: first because they are considered the biggest four international firms who have a wide activity in the Jordanian economic environment; second since they are often used in the previous studies to measure the impact of the type of auditor on the level of CSR practises (Khasharmeh \& Desoky, 2013; Hussainy et al, 2011; Hossain et al, 2006; Xiao et al., 2004). In line with the above, the following hypothesis could be raised: There is no relationship between type of audit firm and level of CSED practices in the Jordanian annual reports.

\section{Type of Financial Market}

The financial performance indicators (e.g. ROA, ROE, ROS) are considered the main factors that have been used widely in the literature of CSR to explore the underlying relationship between firms' corporate financial performance and the level of CSED among listed firms (e.g. Uwuigbe \& Olayinka, 2012; Barnett \& Salomon, 2012; Bayoud et al, 2012; Graafland \& Smid 2004; Salama, 2003; Orlitzky et al. 2003; Rowley \& Berman 2000; McWilliams \& Siegel 2000; Roman, et al 1999; Key \& Popkin 1998).

Although the Return on Equity (ROE) is one of the key indicators that will be used to analyse the level of CSED in Jordanian annual reports, this paper will be also adopted on the classification of ASE for the Jordanian listed companies as an internal factor is compatible with the nature of the paper data (ASE, 2013).

Indeed, the classification of ASE for Jordanian listed companies into two markets is based on the size of the contribution of each company in the local market. The first market represents the best financial performance of companies; while the second market tends to be medium and smaller size in terms of the financial performance in ASE.

Based on the classification above, this paper tends to employ the type of financial market as one of the internal factors that can be performed to explain the level of social and environmental information reported in the annual reports. Thus, the hypothesis raised here is: There is no relationship between level of financial performance and level of CSED practices in the Jordanian annual reports. 


\section{Research Methodology}

\section{Functionalist paradigm as a methodological framework}

According to Ardalan, (2003) functionalist paradigm is a philosophical framework, which theoretically assumes that society has a systematic character and follows a certain order directed toward the production of useful knowledge. Burrell and Morgan, (1979) argue that this paradigm emphasizes the importance of understanding the order, equilibrium and stability in society, by providing more details about social phenomena under investigation. Specifically, Saunders et al, (2007.p.41) stated that "the functionalist paradigm provide a rational explanation of why a particular organizational problem is occurring and develops a set of recommendations within the current structure of the organization's current management".

Moreover, Dhillion and Backhouse, (2001) argue that the functionalist paradigm is considered as a logical foundation to provide rational explanations of human nature based on philosophical hypothesizes, therefore, the functionalist paradigm tends to use scientific tests and quantitative techniques to the analysis of data, and generalized findings.

Hence, in keeping with the views above Ardalan, (2003), Saunders et al, (2007) and Burrell and Morgan, (1979), this paper adopts the philosophy of generating explanatory hypotheses as a basis of social change, which is a usually used statistical technique to interpret the social phenomena being studied.

\section{Disclosure index as a method to measure the level of CSED practices}

Although content analysis is considered the most commonly used method in analytical uses for both qualitative and quantitative data, there are other methods that are used in content analysis where they have the ability to investigate the contents of the disclosure data (Roberts et al 2005). Specifically they stated "More recent studies of social and environmental disclosure have much more sophisticated, and have used various forms of content analysis. Content analysis-based disclosure checklists are designed to measure whether or not an item is disclosed and also to record the form that disclosure takes" (Roberts, et al. 2005. p.249).

Proceeding from the above quotation, this paper seeks to apply the disclosure index as a measurement unit to collect and analyze ideas, structures and meanings related to the social and environmental items in the Jordanian annual reports. This method basically involves analyzing particular texts by assigning sub-categories into a key category. In a clearer definition of this index, Guthrie and Abeysekera (2006: p.11) reported that "a disclosure index is a research instrument comprising a series of pre-selected items which, when scored, provide a measure that indicates a level of disclosure in the specific context for which the index was devised".

It should be noted that the disclosure index method involves a set of methodical procedures interlaced with the objectives of this paper; starting by selecting disclosure categories, defining the documents used, scoring items and sample selection in order to collect the desired data.

Identifying the initial items that should be included in the disclosure index method as a first step to analyze the contexts of corporate reports needs to be clearly defined. In this step, identifying a new set of disclosure items usually depend on the researchers' ability to review appropriate items that used in the similar studies. Therefore, most of the disclosure index items are selected from the previous literature (Hussainey, 2004; Marston and Shrieves, 1991)

In this paper, disclosure index is based on an analytical approach suggested by Ernst and Ernst (1978) as reliable and comprehensive categories for all corporate non-financial practices, as follows: (i) The Ernst and Ernst index captures a variety of social and environmental activities under 7 major categories, namely; Environment, Energy, Fair business practices, Human resources, Community involvement, Products, and Other Activities, thereby 
making it more inclusive on CSED activities than the items included in previous studies (e.g. Deegan et al., 2002; Tsang, 1998; Hackston \& Milne, 1996; Gray et al, 1995b; Zeghal \& Ahmad, 1990); (ii) Ernst and Ernst (1978) have developed "other" category, which can help to add any new activities of CSED practices in this category which do not fall within the main categories (Gray et al., 1995b); (iii)"From a coding perspective, the Ernst and Ernst approach is likely to be more reliable than (other CSR studies) because each coder has (specific options) for each coding decision, and consequently, far fewer possibilities for disagreeing" (Milne and Adler, 1999: p.242).

With regard to the documents used, most studies employing disclosure index have agreed that the corporate annual report is considered as a major source to collect social and environmental information (O'Dwyer, et al., 2005; Idowu \& Towler, 2004; Deegan \& Rankin, 1997; Gray, et al. 1996). For example, Tilt (1994) asserts that corporate annual report gives stakeholders a high degree of credibility of information disclosed more than any other source. It is argued that in its broadest sense, "The annual report not only is a statutory document, produced regularly, but it also represents what is probably the most important document in terms of an organization's construction of its own social imagery" (Gray et al., 1995b, p.83). Consistent with the majority of research efforts, this paper will adopt the same data source that has already been used in the CSR studies to be analysed.

This paper uses an un-weighted approach as a measure to evaluate the level of CSED practices in the annual reports because it assumes that all of items are of equal weights and relative importance (Haddad, 2005). This approach depends on the assigned weight on each item to denote the presence/absence of the disclosure. Thus this approach avoids the autonomous idea of weights in the disclosure checklist (Hasan \& Marston, 2010).

Indeed, the main consideration in the unweighted disclosure checklist is that it deals with all the items as equal, where if a company disclosed any item of social and environmental information in its annual report it will be awarded (1) and if not it will be awarded (0) in the disclosure checklist (Elsayed, 2010; Marston and Shrives, 1991). Thus, the disclosure checklist for the social and environmental practices measures the level of disclosure for each pattern of CSED; also it measures the total of CSED practices, as follows:

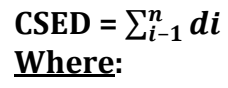

CSED $=$ total of CSED

$d=(1)$ if the item is disclosed, (0) if not

$\mathrm{n}=$ number of items

\section{Sample selection}

A preliminary investigation in the population of this paper showed that the industrial sector contains 69 companies listed in ASE during 2012, 72 companies listed in 2011 and 71 companies listed in 2010. Therefore, after reviewing the classifications of ASE for the industrial sector, the researcher found that there are 6 companies that are delisted from the ASE during the research period. In fact, according to the requirements of financial trading in ASE, these companies have been excluded because they failed to meet disclosing requirements and regulations. Therefore, only 66 companies were eligible as a balanced sample of the research periods for 2010, 2011 and 2012, which is shown in the table below. 
Table 1: Final Sample of Jordanian Industrial Companies in ASE

\begin{tabular}{|l|c|c|c|c|c|}
\hline Name of Sub-Sector & $\begin{array}{c}1^{\text {st }} \\
\text { Market }\end{array}$ & $\%$ & $\begin{array}{c}2^{\text {end }} \\
\text { Market }\end{array}$ & $\%$ & ToT \\
\hline Pharmaceutical \& Medical & 2 & .33 & 4 & .67 & 6 \\
\hline Chemical Industries & 3 & .03 & 7 & .70 & 10 \\
\hline Paper, Cardboard \& Printing & 1 & .25 & 3 & .75 & 4 \\
\hline Food \& Beverages & 3 & .30 & 7 & .70 & 10 \\
\hline Tobacco \& Cigarettes & 2 & 1 & 0 & 0 & 2 \\
\hline Mining \& Extraction & 6 & .43 & 8 & .57 & 14 \\
\hline Engineering \& Construction & 1 & .13 & 7 & .87 & 8 \\
\hline Electrical Industries & 0 & 0 & 4 & 1 & 4 \\
\hline Textiles \& Clothing & 2 & .33 & 4 & .67 & 6 \\
\hline Glass \& Ceramic & 0 & 0 & 2 & 1 & 2 \\
\hline Total & 20 & 30 & 46 & 70 & 100 \\
\hline
\end{tabular}

Note: This table shows the industrial companies listed on ASE website.

An investigation in the above table reveals that there were 66 industrial companies listed in ASE, as a final balanced sample in this paper. These sub-sectors were classified into two markets; 20 (30.3\%) companies in the first market and 46 $(69.7 \%)$ companies in the second market. According to ASE (2012), the classifications of markets into two categories are basic classifications applied to the size of financial performance of companies by dealing with their securities; the first market represents the best financial performance of companies; while the second market tends to be medium and small size in terms of the financial performance in ASE.

Indeed, 198 annual reports from 66 industrial companies listed on ASE during 2010, 2011 and 2012 were selected for this paper. In fact, it should be noted here that the industrial sector was selected in this paper, due to the fact that it is considered the largest sector that affects the environment and society; logically, the researcher expects that the social and environment activities within their annual reports are more than other sectors.

Generally, the process of analysing data from the final sample is to evaluate the impact of internal factors on the level of CSED practices in the annual reports. Thus, this paper uses statistical analysis method in order to answer the research questions that have been developed in the literature review; which will be clear through the next sub-section.

\section{Analysis and Discussion}

\section{Descriptive analyses of the level of CSED practices}

According to Pallant (2001) there are many statistical techniques which can be selected to analyse data. However, Oppenheim (1992) argues that the process of selecting appropriate statistical technique should be based on the nature of the data targeted. Therefore, considering the nature of data in this paper, the data will be analysed using two key methods, namely; (i) descriptive analysis to identify the level of CSED in the Jordanian industrial company listed in AES; and (ii) a statistical analysis by using the SPSS software, in order to investigate any relationships between corporate characteristics and the level of CSED.

This subsection describes the level of CSED practices for the period under review as indicated in chart 5.3 below. The chart indicates that the CSED levels are low and very similar to each other during the survey period of 2010 to 2012 respectively. Specifically, the total amounts of CSED practices during the study period were $35.9 \%, 31.6 \%$ and $32.4 \%$ respectively. This means that the level of CSED in Jordanian listed companies is still below than expected, as shown below. 
Chart 1: tevel of CSED practices during 2010,2011 and 2012

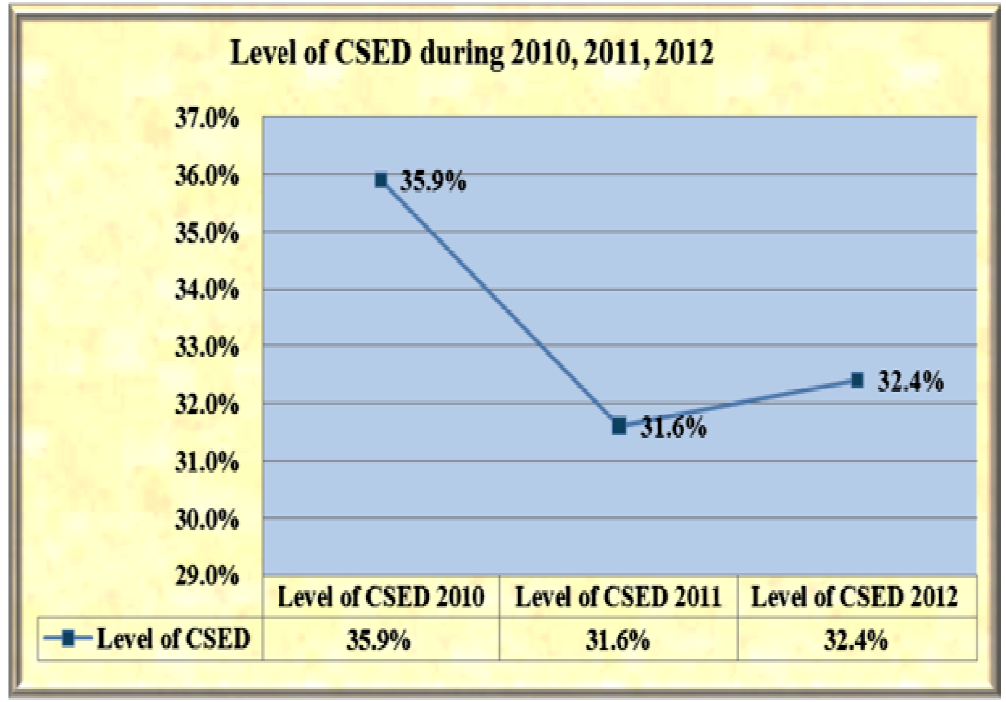

Note: this chart shows the overall total of the level of CSED, which distributed over 3-year

Chart 1 shows that there is an insignificant decrease in the total level of CSED practices from 35.9 per cent in 2010 to 31.6 in 2011. Moreover, the period between 2011 and 2012 indicates that there is a slight increase from 31.6 per cent to 32.4 percent in the level of CSED in annual reports.

This unsatisfactory result is not surprising in this paper, given that the disclosure on CSER information is still voluntary in Jordan business environment. In other words, it might be because of the lack of local regulation that can encourage the practices of CSED. Consequently, the reason of not having a proper regulation might be the lack of cultural awareness of corporate management and government with regards to CSED benefits. This result is confirming the idea of Hossain et al (2012) who state that the reasons behind the low CSER practices "are attributable to lack of regulatory framework, tendency to noncompliance of the laws, socio economic problems, lack of awareness and education in sustainable development, and lack of initiatives from government" (p.2).

In addition to the above arguments, it needs be noted that, the slight differences in the level of CSED practices during the survey periods might be related to the recent political and economic unrest in Arab countries so called Arab spring. The next section discusses random-effects model as a tool that allows measurement of the possible relationships between the determinant factors and the level of CSED practices.

\section{Statistical Analysis of the corporate factors affecting the CSED practices}

In the disclosure literature, there are several tests of the random-effects models which have been widely employed in the quantitative studies as suitable techniques to analyse the causal relationships among variables (Sekaran, 1984). From the software of SPSS, random- effect model is applied in this section as an appropriate regression technique for measuring the relationship between the level of CSED and corporate characteristics.

In line with the above argument, the test of random-effect model is conducted in this paper in order to answer the second research question by analysing the causal relationship between the level of CSED practices and corporate characteristics. Specifically, this relationship between dependent and independent variables will be illustrated in the following equation: 


\section{CSEDit $=a i+\beta 1$ (SIZEit) $+\beta 2$ (PROFit) + $\beta 3$ (AGEit) $+\beta 4$ (INDit) $+\beta 5$ (OWNit) + $\beta 6$ (AUDit) + $\beta 7$ (FIN-PERFit) + uit + $\varepsilon i t$}

\section{Where:}

CSEDit $=$ dependent variable measured by disclosure index.

$\mathrm{ai}=$ the constant measure

$\beta 1($ SIZEit $)=$ Firm size measured by total assets

$\beta 2($ PROFit $)=$ Profitability measured by ROE (return on equity)

$\beta 3$ (AGEit) $=$ Age of firms $\beta 4($ INDit $)=$ Type of industry measured by type of sub-sector

$\beta 5$ (OWNit) = Ownership of firm measured by government or public

$\beta 6($ AUDit $)=$ Type of auditor measured by big 4 audit firms

$\beta 7$ FIN-PERFit $)=$ Financial performance measured by type of market in ASE

uit $=$ Error term

$\varepsilon i t=$ Random error term

From table 2, it can be seen that the random effects model is a fit model to produce meaningful statistical results.

\section{Table 2: Model summary of the random effect model}

\begin{tabular}{|c|c|c|c|c|c|c|}
\hline \multirow{2}{*}{ Model 1} & \multirow{2}{*}{$\begin{array}{c}\mathbf{R}^{2} \\
\text { OLS }\end{array}$} & \multirow{2}{*}{$\begin{array}{c}\mathbf{R}^{2} \\
\text { within }\end{array}$} & \multirow{2}{*}{$\begin{array}{c}\mathbf{R}^{2} \\
\text { between }\end{array}$} & \multirow{2}{*}{$\begin{array}{c}\mathbf{R}^{2} \\
\text { overall }\end{array}$} & \multicolumn{2}{|c|}{$\begin{array}{l}\text { Statistical } \\
\text { values }\end{array}$} \\
\hline & & & & & $\begin{array}{c}\text { F- } \\
\text { value }\end{array}$ & $\begin{array}{c}\text { P- } \\
\text { value }\end{array}$ \\
\hline $\begin{array}{c}\text { CSED }^{*} \\
\text { corporate } \\
\text { characteristics }\end{array}$ & $0.352 a$ & 0.0344 & 0.4355 & 0.3392 & 14.72 & .000 \\
\hline
\end{tabular}

The results of table 2 suggest that the random effects model in this study was statistically significant based on the two most important indicators, namely: (i) $\mathrm{F}$ value with $\mathrm{p}$-value and (ii) the $\mathrm{R} 2$ values. Specifically, the (F-value $=14.72$ with $\mathrm{p}$ value $<.000$ ) as the first indicator point out that the results of random effects model are true and statistically reliable at the $(<.001)$ level. Thus, it can be understood that this result absolutely does not come by chance.

The second important result can be explained for the adoption of the randomeffects model through the value of the R2. Statistically, the value of $\mathrm{R} 2$ overall is considered to be a common value that can used to assess whether the random effects model is a good fit to analyse the results or not. In this model, the value of $\mathrm{R} 2$ overall is (0.34), which means that this model explains about 34 per cent of the variability of the level of CSED practices in the Jordanian annual reports.

Based on the validity of the above model, it seems that this model can be used for prediction purposes in the linear relationships between the level of CSED practices and corporate characteristics. Therefore, this model will be developed by analysing the results of the second model summary below. 
Table 3: Coefficients summary of the random effect model

\begin{tabular}{|c|c|c|c|c|c|c|}
\hline \multirow[b]{2}{*}{$\begin{array}{c}\text { Model } \\
1\end{array}$} & \multicolumn{2}{|c|}{ Coefficients } & \multirow{2}{*}{$\begin{array}{c}\mathrm{Z}- \\
\text { value }\end{array}$} & \multirow{2}{*}{$\begin{array}{c}\text { P- } \\
\text { value } \\
\text { Sig. }\end{array}$} & \multicolumn{2}{|c|}{$\begin{array}{c}95 \% \text { Confidence } \\
\text { Interval for B }\end{array}$} \\
\hline & $\mathrm{B}^{(\mathrm{b1}: 2)}$ & $\begin{array}{l}\text { Std. } \\
\text { Error }\end{array}$ & & & $\begin{array}{l}\text { Lower } \\
\text { Bound }\end{array}$ & $\begin{array}{l}\text { Upper } \\
\text { Bound }\end{array}$ \\
\hline (Constant)a & .494 & .061 & 8.16 & .000 & .375 & .612 \\
\hline Firm Size(1M-JD) & $.314^{* *}$ & 8.30 & 3.79 & .000 & 1.52 & 4.77 \\
\hline Return on Equity & .045 & .052 & 0.87 & .386 & -.056 & .146 \\
\hline Firm Age & -.001 & .001 & -10.82 & .410 & -.002 & .001 \\
\hline Type of Industry & .001 & .005 & 0.15 & .878 & -.008 & .010 \\
\hline Ownership & .010 & .042 & 0.24 & .810 & -.072 & .092 \\
\hline Audit Firm & $.086^{* *}$ & .027 & 3.23 & .001 & .034 & .139 \\
\hline Financial Perf & $-.035^{*}$ & .016 & -2.13 & .033 & -.067 & -.003 \\
\hline
\end{tabular}

As can be seen from Table 3, the strongest contributions of corporate characteristics on the level of CSED practices at the $<0.01$ level are from firm size and audit firm. Corporate size is significantly associated with the level of CSED practices by $(\beta=$ .314 , with $\mathrm{p}$ value $<0.000$ ). From the previous result, it can be predicted that for each 1,000,000 JD increase in corporate size, there is an increase in the level of CSED practices by 0.31 percent.

Similarly, at the level $\mathrm{p}<0.01$, the second strongest relationship among corporate characteristics is between type of audit firm and level of CSED practices by $(\beta=$ .086 with $\mathrm{p}<0.01$ ). This result means that the companies audited by Big 4 auditors have provided more social and environmental information by 0.09 percent in their annual reports than the companies without Big 4 auditors.

Furthermore, at the level $<0.05$, the factor of financial performance is also statistically significant with the level of CSE practices by $(\beta=-.035$, with $p<0.03)$. However, this result of $\beta$ coefficients indicates that the nature of this relationship is an inverse relationship, which means that companies listed in the second market have provided more information on CSR practices than the companies listed in the first market by (0.04) percent.
In spite of the significant results obtained from the explanatory variables above; the random effects model also indicates that there are some insignificance relationships in regression test. In particular, the variables of return on equity, age, type of industry, and ownership structure are not significant with CSED practices at the $\mathrm{p}<$ 0.05 level. Indeed, all $p$-values of the above variables were greater than $0.05,(\beta=045$, $p=0.386),(\beta=-.001, p>0.410),(\beta=.001$, $\mathrm{p}>0.878)$ and $(\beta=.010, \mathrm{p}>0.810)$ respectively. Therefore, these results indicate that there is no linear relationship between CSED practices and ROE, age, industry and ownership.

Generally, an examination of the results of random-effects model used in this paper indicates that the impact of corporate characteristics on the level of CSED practices is partially consistent with the results of previous literature. In line with the findings of table 3 , this section discusses the above results by developing hypotheses of the regression model in the below section.

\section{Results and Discussion of Findings}

Ho: There is no relationship between corporate size and level of CSED in the annual reports. 
According to the results on random-effects model, Table 3 suggests that corporate size has a statistically significant influence on the level of CSED practices in the annual reports. In line with this result, the null hypothesis (H0) can be rejected and supporting the alternative hypothesis (H1) that indicates a positive association between the corporate size and the level of CSED practices in the Jordanian annual reports.

This result is basically consistent with the dominant trend in previous literature, which showed that the firm size was statistically in significant relationship with the level and extent of social and environmental information (e.g. Wang et al 2013; Uyar et al 2013; Yao et al, 2011; Parsa \& Kouhy, 2008; Ghazali, 2007; Hanafi 2006; Gray et al., 2001; Hackson \& Milne, 1996; Cowen et al., 1987, and Trotman and Bradley, 1981).

The empirical studies above agreed that 'firm size' has the greater attention in literature as a determinant of disclosure, which affects the level of corporate disclosure. However these studies reveal that the large companies are ready to disclose more information on the social and environmental practices than the small. In the context of stakeholder perspective, Hanafi (2006) argues that the large companies by virtue of their size are facing more potential pressure that may stem from the multiple relationships between internal and external stakeholders, and as such they tend to provide more information on their social practices.

Consistent with stakeholder theory, it can be argued that the main reason for large companies to increase the social and environmental information is to keep good relationships and to avoid potential pressures among stakeholder groups (Smith et al. 2005; McWilliams \& Siegel, 2001and Gray et al. 1996). Based on this view, it can be concluded that the relationship between corporate disclosure and firm size is a significant positive correlation to reject $\mathrm{H} 0$.

\section{Ho: There is no relationship between corporate profitability and level of CSED in the annual reports.}

With regard to the impact of firms' profitability on CSED practices, the empirical evidence of the CSR literature provided mixed results on this relationship. For example, many previous studies found a positive relationship between profitability and level of corporate social and environmental disclosure (e.g. Hussainey et al, 2011; Hanafi, 2006; Haniffa \& Cooke, 2005; Roberts, 1992; Singh \& Ahuja, 1983). In contrast, there are also many studies that show an insignificant relationship between profitability and CSED practices (e.g. Uyar et al 2013; Bayoud \& Kavanagh, 2012; Ghazali, 2007; Naser et al. 2006; Deegan \& Gordan 1996; Hackston \& Maline, 1996; Belkaoui \& Karpik, 1989 and Cowen et al. 1987).

In this study, corporate profitability was hypothesized to have no significant relationship with the level of CSED practices, and indeed the result found suggests that profitability factor is insignificant. Thus, this result supports the null hypothesis (HO) and rejects the alternative hypothesis (H1) that emphasizes that there is no effect for the firms' profitability on the level of CSED practices.

It seems that the negative result in the current study on the relationship between corporate profitability and CESD practices was not consistent with the stakeholders' perspective which states that the corporate profitability is considered as one of the final fundamental purposes for a corporate management, which, in turn, leads to the increase of investors' confidence in the corporate management (Clarkson, 1995 and Carroll, 1991). As Cormier et al., (2005) and Ullman, (1985) believe that the firms that have a reasonable profit, they automatically have a lot of CSED practices; because the profit advantage for companies may lead them ethically to do more practices in socially responsible ways as members of communities. Regardless of the negative result for this factor, it can be understood that the profitability is one of 
the determinants that cannot be ignored due to its impact on the level of CSED.

\section{Ho: There is no relationship between corporate age and level of CSED in the annual reports.}

With regard to the firms' age, it seems that the negative impact between firm's age and level of CSED practices was the prevailing relationship in the suggested model. This result was consistent with the results of previous studies (e.g. Uyar et al 2013; AboSufian, 2012; Yao et al, 2011; Parsa \& Kouhy, 2008; Hossain \& Raza 2007; Haniffa \& Cooke, 2005; and Singh \& Ahuja, 1983) that revealed there is no relationship between level of CSED and company age. Unlike studies that agreed that the firm age may help to explain the level of CSED practices among companies (e.g. Bayoud \& Kavanagh, 2012; Gray et al., 1996; Choi, 1999).

Although the results of previous literature from the perspective of theory of stakeholders did not provide enough evidence on the empirical association between company age and corporate disclosure practices, the literature on CSR disclosure was agreed that the older companies provide more information about social and environmental practices than the smaller ones, because the younger companies are logically smaller in terms of voluntary practices than older firms (Parsa and Kouhy, 2008).

From above, the result in the current study was not consistent with the view of Parsa and Kouhy (2008), which indicates that older firms are more likely to disclose CSR information than younger companies. However, in this study, the negative impact of this factor can be explained that the Jordanian young companies may need to disclose more information to maintain its commitment with the disclosure requirements and to avoid any legal action may lead to delist the company from ASE. Also, it could be argued that these young companies often used the comprehensive disclosure as one of the effective tools to increase investor confidence. For these reasons, the null hypothesis (H0) can be supported and kept.

\section{Ho: There is no relationship between type of industry and level of CSED in the annual reports.}

From the perspective of stakeholder theory, the expected levels of CSED practices basically depend on the variation of companies' activities. In this regard, Patten, (1991) argues that the variations in the levels of CSED practices are a result of the difference in firms' activities and stakeholder's needs as well. For example, Hassan (2010) argues that the industrial companies receive greater attention from stakeholders than non-manufacturing companies. Therefore, these kinds of companies are subjected to more social pressure that might be considered as a motive to provide more CSED practices.

Contrary to expectations, the type of industry in this study has no significant effect on the level of CSED practices, where this result was disagreed with the majority of previous studies that found a positive relationship between type of industry and CSED practices (e.g. e.g. Wang et al 2013; Bayoud \& Kavanagh, 2012; Parsa \& Kouhy, 2008; Rizk et al 2008; Ghazali, 2007; Hanafi 2006; Gray, 2001; Adams 1998; Gamble et al., 1995; Singh \& Ahuja 1983). Indeed, this result can be attributed to similarities in the type of activity, where all companies in this study are considered of an industrial nature only compared with other studies that dealt with both industry activity and non-industrial activity, where the level of corporate disclosure can be clearer if there were a comparison between the industrial and the financial sector.

Based on the result of this study that is not consistent with a suggested model, the null hypothesis ( $\mathrm{HO}$ ) is accepted and the alternative hypothesis (H1) is rejected. Thus, it can be concluded that there is an insignificant association between level of CSED practices and type of industry in the Jordanian listed companies. 


\section{Ho: There is no relationship between ownership structure and level of CSED in the annual reports.}

The result concerning the impact of ownership structure on the level of CSED practices is not statistically significant to explain the level of CSED practices in the Jordanian annual reports. This result is not similar to the results in previous studies, which found a significant relationship between ownership structure and level of non-financial information (e.g. Wang et al 2013; Soliman, et al 2012; Yao et al., 2011; Cormier et al. 2011; Rizk et al. 2008; Ghazali, 2007; Naser et al. 2006; Haniffa \& Cooke, 2005; Gray et al.1995; Patten, 1992; Guthrie \& Parker, 1990; Andrew et al. 1989; and Teoh \& Thong 1984).

The majority of previous studies were based on stakeholder theory as part of societal theories that provided a probable explanation for the relationship between ownership structure and corporate disclosure as one of the key factors that can influence the level of the social and environmental practices (Smith, et al, 2005). In this regard, Haniffa and Cooke, (2005) and Elijido-Ten (2007) believe that the diversity of firms' ownership may help to reduce the confidence gap among stakeholder groups by providing more extensive decisions on voluntary disclosure, which may stem from several perceptions for shareholders about the importance of corporate disclosure.

Although the result of this factor was not consistent with stakeholder theory, this insignificant result can be explained through the difference of the samples' size of the ownership factor. The companies with local ownership structure reached 180, while the remaining companies (18) are the samples of foreign ownership. Therefore, it may be concluded that this view may be the cause behind this insignificant result.

Based on the above, the null hypothesis (HO) must be accepted and the alternative hypothesis (H1) must be rejected; therefore, it can be understood that the ownership structure is not a major characteristic that affects the level of CSED practices in the Jordanian industrial companies.

\section{Ho: There is no relationship between type of audit firm and level of CSED in the annual reports.}

The principle of stakeholder fairness is one of the core insights behind stakeholder theory that is used as an ethical standard to ensure and coordinate the interests of its various stakeholders (Phillips and Freeman, 2003. This principle assumes that the organizational ethics for any company may require a moral obligation to meet stakeholders' needs (Freeman, 1984). The audited financial statements are a part of stakeholders' needs that are used to enhance their confidence in the company's practices. According to this view, it can be considered the type of audit firm is also an important factor to coordinate these interests between firms and stakeholder groups. Therefore, type of audit firm was selected in this study as one of the corporate characteristics that affects the corporate disclosure practices.

With regard to the hypothesis which states that there is no association between type of audit firm and level of CSED; it can be argued that all results on this factor rejects the hypothesis above (HO) and accepts the view (H1) which states that there is a significant impact of type of audit firm on the level of CSED practices. This result in fact supports the results of t-test about this factor, which found that the Jordanian companies that deal with the Big-4 firms to audit their financial statements have provided more information on the practices of CSED than the companies with non-Big 4.

In line with the stakeholder perspective, it can be noted that the result above is consistent with the dominant trend in previous literature, which found that the type of audit firm is significantly associated with CSR information (e.g. Uyar et al 2013; Ajiboladea \& Uwuigbeb 2013; Hussainy et al. 2011; Haniffa \& Cooke, 2005; Xiao et al., 2004; Chau \& Gray, 2002; Choi, 1999) 
Ho; There is no relationship between financial performance and level of CSED in the annual reports.

With regard to the level of financial performance as one of the internal factors that can affect the corporate disclosure, it can be observed that the majority of previous studies employed ROA, ROE and EPS as indicators to explore the underlying relationship between firms' corporate financial performance and the level of CSR disclosure (e.g. Uwuigbe \& Olayinka, 2012; Barnett \& Salomon, 2012; Bayoud et al, 2012; Graafland \& Smid 2004; Salama, 2003; Orlitzky et al. 2003; Rowley \& Berman 2000; McWilliams \& Siegel 2000; Key \& Popkin 1998).

Unlike previous literature which identifies accounting measures to explore the relationship between firm performance and corporate disclosure, this study identifies classification of ASE into first and second tier market as a financial standard for performance of the Jordanian listed companies (ASE, 2014). Given that this domestic financial measure is compatible with the nature of the study data, it was used as an internal factor that can have an impact on the level of CSED in the Jordanian reports.

Based on the above, the final hypothesis in the current study was checked, where the statistical indicators in table 3 showed that there is a statistically significant relationship between the level of financial performance and level of CSED practices.

Despite the fact that the model above indicates that the relationship among the above factors was a statistically significant predictor, this type of associations is an inverse relation, which means that the practices of CSED are mostly associated with the companies listed in the second market more than the first market. This result in fact supports the analysis of the $t-$ test result on the differences between dummy variables of this factor, which indicated that companies in the second market face tougher legislation for the disclosure in the annual reports than the first market.
Overall, the results above provide evidence on a clear relationship between financial performance and level of CSED practices, lead us to reject the null hypothesis (H0) and accept the alternative hypothesis.

\section{Conclusions}

In order to have a smooth business environment, there is need to verify all financial and non-financial aspects of the company. In accounting literature on CSED topic, it is stated that the CSED is considered as the stakeholder's right that needs to be disclosed. Moreover, it is known as one of the preferred methods that can be used to reduce and avoid the conflicts between firms and their stakeholders.

Based on the above argument, this paper sought to investigate one of the most important issues concerning the impacts of determinant factors on the level of CSED practices in the Jordanian annual reports. Therefore, the five points below represent a comprehensive summary about this investigation:

- Despite the importance of this type of disclosures, developing countries still suffer from lack of social and environmental awareness among the stakeholders, as well as, there is still a weakness in the government's regulations on CSED practices.

- CSED studies in developed countries are more interested to compare with sibling. But, the literature points out that, nowadays, developing countries have become more interested toward this field.

- This paper has employed the philosophical assumptions underlying the functionalist paradigm as an effective framework to interpret the quantitative results. Keeping with the above paradigm used, this paper also used disclosure index as an appropriate approach to analyze the quantitative data.

- Descriptive statistics showed that there was a relatively low level of CSED practices in the annual reports, which 
ranged between $36 \%$ - 32\% during the survey period $2010-2012$.

- Statistically, the results revealed that corporate size, type of audit firm and financial performance are the strongest factors that have affected the Jordanian corporate disclosure; while, other factors are not associated with level of CSED practices.

\section{References}

- Abu-Baker, N. \& Nasser, K. (2000) Empirical Evidence on Corporate Social Disclosure Practices in Jordan. International Journal of Commerce \&Management, 10, $18-34$

- Abu-Sufian, M (2012) CSR Disclosure in Bangladesh. Global Journal of Management \& Business Research, 12, 148155.

- $\quad$ Adams, C. \& Kuasirikun, N. (2000) A Comparative Analysis of Corporate Reporting on Ethical Issues by UK \& German Chemical \& Pharmaceutical Companies. European Accounting Review, 9, 53-79.

- $\quad$ Adams, C., Hill, Y. \& Roberts, C. (1998) Corporate Social Reporting Practices in Western Europe: Legitimating Corporate Behavior? The British Accounting Review, 30, 1-21.

- Ahmad, J. U. \& Karim, A K M. W. (2005), Determinants of IAS disclosure compliance in emerging economies: Evidence from exchange listed companies in Bangladesh, Working Paper Series (21), Victoria University of Wellington, New Zeal\&.

- Ahmad, N. (2004) Corporate Environmental Disclosure in Libya: Evidence \& Environmental Determinism Theory, Napier University, "Unpublished PhD Thesis".

- Ali, W. \& Rizwan, M (2013) Factors Influencing Corporate Social \& Environmental Disclosure (CSED)
Practices in the Developing Countries: An Institutional Theoretical Perspective International Journal of Asian Social Science, 3, 590-609.Online at: http://onlinelibrary.wiley.com/doi/10.10 02/csr.132/pdf [02 May 2013]

- Alnajjar, F. (2000) Determinants of Social Responsibility Disclosures of U.S. Fortune 500 Firms: An Application of Content Analysis Advances in Environmental Accounting \& Management 1, 163-200

- Al-Oquili, O. \& Kouhy, R. (2006) Future Environmental Regulation Issues to Promote Energy Efficiency. J. American Society of Civil Engineers. 132(2), 67-73.

- Andrew, B., Gul, F., Guthrie, J., \& Teoh, H (1989) A Note On Corporate Social Disclosure Practices In Developing Countries: The Case of Malaysia \& Singapore. British Accounting Review, 21, 371- 376

- Ardalan, K. (2003) On Clinical Research in Finance. International Journal of Social Economics, 30, 1038-1048.

- $\quad$ Aribi, Z. A. (2009) An Empirical Study of CSR \& its Disclosure in Islamic Financial Institutions, Napier University, "Unpublished PhD Thesis"

- ASE, Amman Stock Exchange (2014) available online at: http://www.ase.com.jo/en/equities (Date Accessed 17-01-2014).

- Azizul-Islam, M. (2009) Social \& Environmental Reporting Practices of Organizations Operating in, or Sourcing Products from, a Developing Country: Evidence from Bangladesh, RMIT University, "Unpublished PhD Thesis"

- Balabanis, G. Philips, H. \& Lyall, J. (1998), "CSR \& Economic Performance in the Top of British Companies: Are they linked? European Business Review, Vol. 98, No. 1, pp. 25-44.

- Barako DG, Hancock P \& Izan HY (2006) Factors Influencing voluntary 
corporate disclosure by Kenyan companies. Corporate Governance: An International Review. 14, 107 - 25

- $\quad$ Barnett, M. \& Salomon, R. (2012) Does It Pay To Be Really Good? Addressing The Shape of The Relationship between Social \& Financial Performance, Strategic Management Journal, 33 1-40, Online at: http://papers.ssrn.com/sol3/papers.cfm? Abstract id=1860985 [4 Jun 2013].

- Bayoud, S. \& Kavanagh, M. (2012) Factors Influencing Levels of CSR Disclosure by Libyan firms: A Mixed study, International Journal of Economics \& Finance, 4, 13-29

- $\quad$ Belal, R \& Owen, D (2007) The Views of Corporate Managers on the Current State of, \& Future Prospects for, Social Reporting in Bangladesh: An EngagementBased Study, Accounting, Auditing \& Accountability Journal 20, 472-494.

- $\quad$ Belal, R \& Momin, M (2009) Corporate Social Reporting (CSR) in Emerging Economies: A Review \& Future Direction. In: Tasmania, M. \& Uddin, S. (eds.) Research in Accounting in Emerging Economies. Emerald Group Publishing Limited.

- Belal, R (1999) Corporate Social Reporting in Bangladesh, Social \& Environmental Accountability Journal, 19, 8-12.

- Belkaoui, A \& Karpik, P (1989) Determinants of the Corporate Decision to Disclose Social Information, Accounting, Auditing \& Accountability Journal, 2, 36-51

- Blacconiere, G \& Patten, M 1994. Environmental Disclosures, Regulatory Costs, \& Changes in Firm Value. Journal of Accounting \& Economics. 18, 357-377.

- Brammer, S. \& Pavelin, S. (2006) Voluntary Environmental Disclosures by Large UK Companies, Journal of Business Finance \& Accounting, 33, 1168-1188

- Branco, M. \& Rodrigues, L. (2008) Factors Influencing Social Responsibility
Disclosure by Portuguese Companies, Journal of Business Ethics, 83, 685-701.

- Burrell, G. \& Morgan, G. (1979) Sociological Paradigms \& Organizational Analysis: Elements of the Sociology of Corporate Life, London, Heinemann.

- Carroll, B. (1991) The Pyramid of CSR: Toward the Moral Management of Organizational Stakeholders. Business Horizons, 34, 39-48.

- Clarkson, M. E. (1995) A Stakeholder Framework for Analyzing \& Evaluating Corporate Social Performance. The Academy of Management Review, 20, 92117.

- Cormier, D. \& Gordon, I. (2001) An Examination of Social \& Environmental Reporting Strategies. Accounting, Auditing \& Accountability Journal, 14, 587-616

- Cormier, D. \& Magnan, M. (2003a) Does disclosure matter? CA Magazine, 136, 43-45.

- Cormier, D. \& Magnan, M. (2003b) Environmental Reporting Management: A Continental European Perspective. Journal of Accounting \& Public Policy, 22, 43-62.

- $\quad$ Cormier, D., Ledoux, M., Magnan, M. \& Aerts, W. (2010) Corporate Governance \& Information Asymmetry between Managers \& Investors. Corporate Governance, 10, 574-589.

- Cormier, D., Magnan, M. \& VanVelthoven, B. (2005) Environmental Disclosure Quality in Large German Companies: Economic Incentives, Public Pressures or Institutional Conditions? European Accounting Review, 14, 3-39.

- Cowen, S., Ferreri, L. \& Parker, L. (1987) The Impact of Corporate Characteristics on Social Responsibility Disclosure: A Typology \& Frequency-Based Analysis. Accounting, Organizations \& Society, 12, 111-122.

- $\quad$ Deegan, C. \& Gordon, B. (1996) A Study of the Environmental Disclosure Practices

Tareq Bani-Khalid, Reza Kouhy and Aminu Hassan (2017), Journal of Accounting and Auditing: Research \& Practice, DOI: 10.5171/2017.369352 
of Australian Corporations. Accounting \& Business Research, 26, 187-199.

- Deegan, C. \& Rankin, M. (1997) The Materiality of Environmental Information to Users of Annual Reports. Accounting, Auditing \& Accountability Journal, 10, 562581

- Deegan, C. \& Voght, P. (2000) Firms' Disclosure Reactions to Major Social Incidents: Australian Evidence. Accounting Forum, 24, 101-130

- Deegan, C. (2002) The Legitimizing Effect of Social \& Environmental Disclosures - A Theoretical Foundation. Accounting, Auditing \& Accountability Journal, 15, 282- 311

- Deegan, C. (2002), "Introduction- the legitimizing effect of social \& environmental disclosures-a theoretical foundation", Accounting, Auditing \& Accountability Journal, Vol.15, No.3, pp 282-311

- Deegan, C., Rankin, M. \& Tobin, J. (2002) An Examination of the Corporate Social \& Environmental Disclosures of BHP from 1983-1997: A Test of Legitimacy Theory. Accounting, Auditing \& Accountability Journal, 15, 312-343

- Dhillon, G. \& Bachouse, J. (2001) Current Directions in IS Security Research: Towards Socio-Organizational Perspectives. Information Systems Journal, 11, 127-153.

- D'Amato, Alessia; Henderson, Sybil; and Florence, Sue (2009). Corporate Social Responsibility and Sustainable Business: A Guide to Leadership Tasks and Functions. North Carolina: Center for Creative Leadership.

- Elijido-Ten, E. O. (2007) "Applying Stakeholder Theory to Analyze Corporate Environmental Performance: Evidence from Australian Listed Companies," Asian Review of Accounting, 15 .164-184.

- $\quad$ Eljayash, K., M. Kavanagh, et al. (2012) Environmental Disclosure Practices in
National Oil \& Gas Corporations \& International Oil \& Gas Corporations Operating in Organization of Arab Petroleum Exporting Countries. International Journal of Business, Economics \& Law 2, 35-52

- Elsayed, A. N. M. E. (2010) The Key Determents of the Voluntary Adoption of Corporate Internet Reporting \& its Consequence on Firm Value: Evidence from Egypt. PhD Thesis, University of Plymouth

- Epstein, J \& Freedman, M. (1994) Social Disclosure \& Individual Investor. Accounting, Auditing \& Accountability Journal, 7, 94-109

- Ernst \& Ernest (1978) Social Responsibility Disclosure Surveys, Clevel $\&, \mathrm{OH}$

- Finer M, Jenkins CN, Pimm SL, Keane B, \& Ross C (2008) Oil \& Gas Projects in the Western Amazon: Threats to Wilderness, Biodiversity, \& Indigenous Peoples. Online at:

http://www.plosone.org/article/info\%3A doi\%2F10.1371\%2Fjournal.pone.0002932

- Freedman, M. \& Jaggi, B. (1988) An Analysis of the Association between Pollution Disclosure \& Economic Performance. Accounting, Auditing \& Accountability Journal, 1, 43-58

- Freeman, E. (1983) Stockholders \& Stakeholders: A New Perspective on Corporate Governance. California Management Review, 25, 88-106.

- Freeman, R. E. (1984) Strategic Management a Stakeholder Approach Boston, Boston: Pitman Publishing, 1984.

- Friedman A.L. \& Miles, S. (2001) Socially Responsible Investment \& Corporate Social \& Environmental Reporting In the UK: An Exploratory Study. British Accounting Review 33, 523-548

- Gamble, G., Hsu, K., Kite, D. \& Radtke, R. (1995) Environmental Disclosures in 
Annual Reports\& 10Ks: An Examination. Accounting Horizons, 9, 34-54

- Gao, S., Heravi, S. \& Xiao, J. (2005) Determinants of Corporate Social \& Environmental Reporting in Hong Kong: A Research Note. Accounting Forum, 29, 233242.

- Gautam, R. \& Singh, A. (2010) CSR Practices in India: A Study of Top 500 Companies. Global Business \& Management Research: An International Journal, 2, 41-56.

- Ghazali, N. M. (2007) Ownership Structure \& CSR Disclosure: Some Malaysian Evidence. Corporate Governance, 7, 251-266.

- Graafl\&, J. J. \& Smid, H. (2004) Reputation, CSR \& Market Regulation. Tijdschrift voor Economie en Management, XLIX, 271-308. Online at: Http://mpra.ub.unimuenchen.de/20772/1/MPRA paper 207 72.pdf [17-April 2013]

- Gray, R., Adams, C. A. \& Owen, D. (1996) Accounting \& Accountability: Changes \& Challenges in Corporate Social \& Environmental Reporting, Prentice-Hall.

- Gray, R., Javad, M., Power, D. \& Sinclair, C. (2001) Social \& Environmental Disclosure \& Corporate Characteristics. A Research Note \& Extension. Journal of Business Finance \& Accounting, 28, 327356.

- $\quad$ Gray, R., Kouhy, R. \& Lavers, S. (1995) Corporate Social \& Environmental Reporting: A Review of the Literature \& a Longitudinal Study of UK Disclosure. Accounting, Auditing \& Accountability Journal, 8, 47-77

- Guthrie, J. \& Abeysekera, I. (2006) Content Analysis of Social, \& Environmental Reporting: What is new? Journal of Human Resource Costing \& Accounting, 10, 114-124

- Guthrie, J. \& Parker, L. (1989) Corporate Social Reporting: A Rebuttal of
Legitimacy Theory. Accounting \& Business Research, 19, 343-353.

- Guthrie, J. \& Parker, L. (1990) Corporate Social Disclosure Practice: A Comparative International Analysis. Advances in Public Interest Accounting, 3, 159-175.

- Hackston, D. \& Milne, M. (1996) Some Determinants of Social \& Environmental Disclosures in New Zeal\& Companies. Accounting, Auditing \& Accountability Journal, 9, 77-108

- Hadad, A. (2005) The Impact of Voluntary Disclosure Level on the Cost of Equity Capital in an Emerging Capital Market: the Case of the Amman Stock Exchange. PhD Thesis, University of East Anglia, UK

- Hail, L. (2002). The impact of voluntary corporate disclosures on the exante cost of capital for Swiss firms. European Accounting Review 11, 741-777

- Hanafi, R. (2006) An Exploration of Corporate Social \& Environmental Disclosure in Egypt \& the UK: A Comparative Study, PhD Thesis, University of Glasgow, UK.

- Haniffa, R. \& Cooke, T. E. (2005) The Impact of Culture \& Governance on CSR Reporting. Journal of Accounting \& Public Policy, 24, 391-430.

- $\quad$ Harrison, J. S. \& Freeman, R. E. (1999). Stakeholders, Social Responsibility \& Performance: Empirical Evidence \& Theoretical Perspectives. Academy of Management Journal, 42, 479-485

- Harte, G. \& Owen, D. (1991) Environmental Disclosure in the Annual Reports of British Companies: A Research Note. Accounting, Auditing \& Accountability Journal, 4, 51-61

- Hassan, O. \& Marston, C. (2010) Disclosure Measurement in the Empirical Accounting Literature a Review Article. Economics \& Finance Working Paper, Brunel University. Online at: 
http://bura.brunel.ac.uk/bitstream/2438/ 5047/1/1018\%5B1\%5D.pdf $\quad[19$ Dec 2014]

- Hassan, T. (2010) CSR Disclosure: An Examination of Framework of Determinants \& Consequences; PhD Thesis, Durham University, UK

- Healy, P. M. \& Palepu, K. G. (2001) Information Asymmetry, Corporate Disclosure, \& the Capital Markets: A Review of the Empirical Disclosure Literature. Journal of Accounting \& Economics, 31, 405-440.

- Hegde, P., Bloom, R. \& Fuglister, J. (1997) Social Financial Reporting in India. The International Journal of Accounting, 32, 155-172.

- Hail, L. (2002) The impact of voluntary corporate disclosures on the ex-ante cost of capital for Swiss firms, European Accounting Review, 11, 741-73.

- Holder-Webb, L., Cohen, R., Nath, L. \& Wood, D. (2009) The Supply of CSR Disclosures among U.S. Firms. Journal of Business Ethics, 84, 497-527.

- Hossain. M., Islam. K. \& \&rew. J., (2006) Corporate Social \& Environmental Disclosure in Developing Countries: Evidence from Bangladesh. Online at: http://ro.uow.edu.au/cgi/viewcontent.cgi? article $=1194 \&$ context $=$ commpapers $\quad[18$ April-2013]

- Huafang, X. \& Jianguo, Y. (2007) Ownership Structure, Board Composition \& Corporate Voluntary Disclosure: Evidence from Listed Companies in China. Managerial Auditing Journal, 22, 604-619.

- Hussainey, K. S. (2004) Study of the Ability of (Partially) Automated Disclosure Scores to Explain the Information Content of Annual Report Narratives for Future Earnings. PhD Thesis, University of Manchester

- Hussainy K., Elsayed M. \& Abdelrazek M. (2011) Factors affecting CSRD in Egypt,
Corporate Ownership \& Control journal, 8, $432-443$

- Idowu, S. O. \& Towler, B. A. (2004) A Comparative Study of the Contents of CSR Reports of UK Companies. Management of Environmental Quality, 15, 420- 437

- Imam, S. (2000) Corporate Social Performance Reporting in Bangladesh. Managerial Auditing Journal, 15, 133-142.

- Ince, D. (1998) Corporate, Social \& Environmental Reporting (CSER): An Application of Stakeholder Theory. PhD Thesis, University of Exeter, unpublished PhD Thesis

- Islam, M. A. \& Deegan, C. (2008) Motivations for an Organization within a Developing Country to Report Social Responsibility Information: Evidence from Bangladesh. Accounting, Auditing \& Accountability Journal, 21, 850- 874

- Ismail, K. \& Ibrahim A. H. (2010) Social \& Environmental Disclosure in the annual Reports of Jordanian Companies. Issues in Social \& Environmental Accounting, 2, 198210.

- Jensen, C. \& Meckling, H. (1976) Theory of the Firm: Managerial Behavior, Agency Costs \& Ownership Structure. Journal of Financial Economics, 3, 305-360.

- Jones S., G. Frost, J. Loftus and S. Van Der Laan, (2007), 'An Empirical Examination of the Market Returns and Financial Performance of Entities Engaged in Sustainability Reporting' Australian Accounting Review, 17, 78-87.

- Kakabadse, N., Rozuel, C. \& Lee-Davies, L. (2005) CSR \& Stakeholder Approach: A Conceptual Review. Business Governance \& Ethics, 1, 277-302.

- Kelly J., (1981) Australian Social Responsibility Disclosure: Insights into Contemporary Measurement, Accounting \& Finance, 21, 97-104.

- Key, S. \& Popkin, S. J. (1998) Integrating Ethics into the Strategic

Tareq Bani-Khalid, Reza Kouhy and Aminu Hassan (2017), Journal of Accounting and Auditing: Research \& Practice, DOI: $10.5171 / 2017.369352$ 
Management Process: Doing Well-Doing Good. Management Decision, 36, 331-338.

- Khasharmeh, H. A. and Desoky, A. M. (2013). On-line CSED: The Case of the Gulf Cooperation Council Countries, Global Review of Accounting and Finance , 4, 39 64

- Langtry, B. (1994) Stakeholders \& the Moral Responsibilities of Business. Business Ethics Quarterly, 4, 431-443.

- Lundholm, R. \&. Myers, P. (2002). "Bringing the future forward: The effect of disclosure on the returns-earnings relation, Journal of Accounting Research, Vol. 40, No. 3, June, pp. 809-839

- Macarulla F. \& Talalweh, M, (2012) Voluntary Corporate Social Responsibility Disclosure: A Case Study of Saudi Arabia, Jordan Journal of Business Administration, Vol 8, No. 4, pp 815-830

- Marcoux, A. M. (2003) A Fiduciary Argument against Stakeholder Theory. Business Ethics Quarterly, 13, 1-24.

- Marston, C. L. \& Shrives, P. J. (1991) The Use of Disclosure Indices in Accounting Research: A Review Article. The British Accounting Review 23, 195210.

- Mathews, M. R. (1997) Twenty-Five Years of Social \& Environmental Accounting Research Is there a Silver Jubilee to Celebrate? Accounting, Auditing \& Accountability Journal, 10, 481- 531

- Mcgure, J., Dow, S. \& Argheyd, K. (2003) CEO Incentives \& Corporate Social Performance. Journal of Business Ethics, 45, 341-359.

- $\quad$ Mcwilliams, A. \& Siegel, D. (2001) CSR: A Theory of the Firm Perspective. The Academy of Management Review, 26, 117127.

- $\quad$ Milne, M. \& Adler, R. (1999) Exploring the Reliability of Social \& Environmental Disclosures Content Analysis. Accounting,
Auditing \& Accountability Journal, 12, 237 256

- Momin, M. A. (2006) CSR \& Reporting by Multinational Corporations in Bangladesh: an exploration. PhD Thesis, University of Glasgow, UK

- Murray, A., Sinclair, D., Power, D. \& Gray, R. (2006) Do Financial Markets Care about Social \& Environmental Disclosure? Further Evidence \& Exploration from the UK. Accounting, Auditing \& Accountability Journal, 19, 228- 255

- Naser, K., AL-Hussaini, A., AL-kwwari, D. \& Nuseibeh, R. (2006) Determinants of Corporate Social Disclosure in Developing Countries: The Case of Qatar. Advances in International Accounting, 19, 1-23.

- $\quad$ Ness, K. E. \& Mirza, A. M. (1991) Corporate Social Disclosure: A Note of Agency Theory, British Accounting Review, 23, 211-217.

- Newsona, M. \& Deegan, C. (2002) Global Expectations \& their Association with Corporate Social Disclosure Practices in Australia, Singapore, \& South Korea. The International Journal of Accounting, 37, 183- 213

- O'Dwyer, B. (2002) Managerial Perceptions of CSR Disclosure: An Irish Story. Accounting, Auditing \& Accountability Journal, 15, 406-436

- O'Dwyer, B., Unerman, J. \& Bradley, J. (2005) Perceptions on the Emergence \& Future Development of CSR Disclosure in Irel\&: Engaging the Voices of NonGovernmental Organizations. Accounting, Auditing \& Accountability Journal, 18, 1443

- Oppenheim, A. (1992). Questionnaire Design, Interviewing \& Attitude Measurement, London, Pinter. Issue Journal of Community \& Applied Social Psychology Journal of Community \& Applied Social Psychology, 4, 371-372

- $\quad$ Orlitzky, M., Schmidt, F.L., \& Rynes, S.L. (2003) Corporate Social \& Financial

Tareq Bani-Khalid, Reza Kouhy and Aminu Hassan (2017), Journal of Accounting and Auditing: Research \& Practice, DOI: 10.5171/2017.369352 
Performance: A Meta-analysis. 24, 403441. Online at: http://communitywealth.org/pdfs/articlespublications/sri/article-orlitzky-et-al.pdf [22 Feb 2013].

- Pallant, J. (2001). SPSS survival manual, Buckingham: Open University Press.

- $\quad$ Parsa, S. \& Deng, L. X. (2008) Capital Markets: Reactions to Social Information Announcements. International Journal of Accounting \& Finance, 1, 107 - 120.

- Parsa, S. \& Kouhy, R. (2008) Social Reporting by Companies Listed on the Alternative Investment Market. Journal of Business Ethics, 79, 345-360.

- Patten, M. (1992) Intra-Industry Environmental Disclosures in Response to the Alaskan Oil Spill: A Note on Legitimacy Theory, 1992

- Patten, M. (2002).The Relation between Environmental Performance \& Environmental Disclosure: A Research Note. Accounting, Organizations \& Society, 27, 763-773.

- $\quad$ Rettab B, Brik B, \& Mellahi K (2009). A Study of Management Perceptions of Impact of CSR on Organizational Performance in Emerging Economic: A Case of Dubai. Journal of Business Ethics, 89:317-390

- Rizk, R., Dixon, R. \& Woodhead, A. (2008) Corporate Social \& Environmental Reporting: A Survey of Disclosure Practices in Egypt. Social Responsibility Journal, 4, 306-323.

- Roberts, C. B., Weetman, P. \& Gordon, P. (2005) International Financial Reporting: A Comparative Approach, London, Pearson Education.

- $\quad$ Roberts, R. W. (1992) Determinants of CSR Disclosure: An Application of Stakeholder Theory.

- Roman, M., Haybor, S. \& Agle, R. (1999) The Relationship between Social \&
Financial Performance: Repainting a Portrait. Business \& Society, 38, 109-125.

- $\quad$ Rowley, T. \& Berman, S. (2000) A Br\& New Br\& of Corporate Social Performance. Business \& Society, 39, 397-418.

- Sahay, A. (2004) Environmental Reporting by Indian Corporations. CSR \& Environmental Management, 11, 12-22.

- $\quad$ Said, R.,Hariri, H., Zainuddin, Y. \& Haron, H (2011) Developments in Corporate Governance \& Responsibility: Chapter 9 The Extent of Disclosure of CSR in Malaysia. Governance in the Business Environment, 2, 177-194

- Salama, A. (2003) The Relationship Between Environmental Disclosure, Environmental Reputation \& Firm Financial Performance. PhD Thesis, University of Nottingham. Unpublished PhD Thesis

- Samaha, K. \& Dahawy, K. (2011) An Empirical Analysis of Corporate Governance Structures \& Voluntary Corporate Disclosure in Volatile Capital Markets: Egyptian Experience. International Journal of Accounting, Auditing \& Performance Evaluation. 7, 61 93

- $\quad$ Saunders, M., Lewis, P. \& Thornhill, A. (2007) Research Methods for Business Students, Harlow, Hall-Financial Times

- Sekaran, U (1984), Research Methods For managers: A Skill-Building Approach, John Wiley \& Sons, Inc., USA.

- $\quad$ Silberhorn, D. \& Warren, R. C. (2007) Defining CSR: A View from Big Companies in Germany \& the UK. European Business Review, 19, 352-372.

- Singh, D. R. \& Ahuja, J.M. (1983). Corporate social reporting in India. The International Journal of Accounting, 18, 151-169

- Smth, J., Adhikari, A. \& Rasoul, H. T. (2005) Exploring differences in social disclosures internationally: A stakeholder 
perspective. Journal of Accounting \& Public Policy, 24, 123-151.

- Solabomi Ajiboladea \& Uwalomwa Uwuigbe (2013) Effects of Corporate Governance on Corporate Social \& Environmental Disclosure among Listed Firms In Nigeria. European Journal of Business \& Social Sciences, 2, 76-92

- Soliman .M, El din.m \& Sakr.a (2012), Ownership Structure \& CSR - An Empirical Study of The Listed Companies, International Journal of Social Science, 5, 63-74.

- Solomon, A \& Lewis, L. (2002) Incentives \& Disincentives for Corporate Environmental Disclosure. Business Strategy \& the Environment, 11, 154-169.

- Teoh, H.-Y. \& Thong, G. (1984). Another Look at CSR \& Reporting: An Empirical Study in a Developing Country. Accounting, Organizations \& Society, 9, 189-206.

- Tilt, C. A. (1994) The Influence of External Pressure Groups on Corporate Social Disclosure: Some Empirical Evidence. Accounting, Auditing \& Accountability Journal, 7, 47-72

- $\quad$ Trotman, K. T. \& Bradley, G. W. (1981) Associations between Social Responsibility Disclosure \& Characteristics of Companies. Accounting, Organizations \& Society, 6, 255 - 362.

- Tsang, E. W. (1998) A Longitudinal Study of Corporate Social Reporting in Singapore. Accounting, Auditing \& Accountability Journal, 11, 624-635

- Ulmann, A. (1985) Data in Search of a Theory: A Critical Examination of the Relationships among Social Performance, Social Disclosure, \& Economic Performance of U. S. Firms. The Academy of Management Review, 10, 540-557.

- Uwuigbe, U. \& Olayinka M. U. (2011). Corporate Social \& Environmental
Disclosure in Nigeria: A Comparative Study of the Building Material \& Brewery Industry. International Journal of Business \& Management, 6, 258-264

- Uwuigbe, U. \& Olusami, O. (2012) An Evaluation of Stakeholders \& Accounting Teachers Perception of Corporate Social \& Environmental Disclosure Practice in Nigeria. An International Multidisciplinary Journal, 7,352-365

- $\quad$ Waddock, S. A. \& Graves, S. B. (1997) The Corporate Social PerformanceFinancial Performance Link. Strategic Management Journal, 18, 303-319.

- Williams, S. M. (1999) Voluntary Environmental \& Social Accounting Disclosure Practices in the Asia-Pacific Region: An International Empirical Test of Political Economy Theory. The International Journal of Accounting, 34, 209-238.

- Wilson, R. (1997) Islamic Finance \& Ethical Investment. International Journal of Social Economics, 24, 1325-1342.

- Xiao, Z. Yang, H. \& Chow, C. (2004): Patterns \& Determinants of Internet Based Corporate Disclosure in China. Journal of Accounting \& Public Policy, 23, 191-225.

- Yao, S., Wang, J. \& Song, L. (2011) Determinants of Social Responsibility Disclosure: Chinese Firms. Online at: http://www.nottingham.ac.uk/cpi/docum ents/discussion-papers/discussion-paper72-csr.pdf [30 May 2013].

- Zamir, A. Hasan, A., \& Mirza, G. (2012) Trend of Corporate Environmental Reporting in Pakistan. International Proceedings of Economics Development \& Research, 57: 117-121.

- Zeghal, D. \& Ahmed, S. (1990) Comparison of Social Responsibility Information Disclosure Media Used by Canadian Firms. Accounting, Auditing \& Accountability Journal, 3, 38-53 


\section{Notes}

Northern Cement; Sheba Metal Casting;

Village Food and Vegetable Oil and Siniora Food; Dulayl Industrial \& Estate; 